\title{
O saber do espectador e o saber do telespectador*
}

*Texto traduzido do francês por Reto Melchior.

FrançOIS Jost

Centre d'étude des images et des sons médiatiques/Sorbonne Nouvelle 


\section{Resumo}

O artigo discute questões básicas de narratologia, a partir de uma crítica a posições defendidas por Gérard Genette, mostrando que tal concepção não se ajusta bem aos textos visuais do cinema e da televisão. Começa por estabelecer uma distinção entre ver e saber, imbricadas nas relações narratológicas, que os teóricos desta disciplina costumam utilizar indiferentemente. Convoca, para ilustrar sua proposta, um exemplo heurístico, o atentado de 11 de setembro perpetrado contra o World Trade Center. Mostra, então, que o ver não pode deixar de prescindir do saber - as imagens do atentado, por si mesmas, não são reconhecidas enquanto o telespectador não consegue estabelecer um laço entre elas e uma dimensão do mundo que, em TV, aparece vinculada ao real ou ao fictício ou ao lúdico. A partir da análise do evento, revela que as imagens só podem ser aceitas como violentas quando perpassam pela somatização humana.

\section{Palavras-chave}

narratologia, ver, saber, televisão, atentado de 11 de setembro

\section{Abstract}

This article discusses basic questions of narratology, from a criticism to different opinions defended by Gerard Genette, demonstrating that such conceptions does not fit to the visual texts of the cinema and television. It begins by establishing a distinction between seeing and knowing embedded in the narratologic relations, which are indifferently utilized by this discipline theorists. It convokes, in order to illustrate its purpose, a heuristic example: the September $11^{\text {th }}$ attempt, perpetrated against the World Trade Center. This way, it shows that seeing is related to knowing - the images of the attempt, by themselves, are not recognized while the viewer can not establish a link between them and a dimension of the world which, on TV, appears linked to the real, to the fictional or to the ludic. From the analysis of the mentioned event, it reveals that the images just can be accepted as violent when passes through the human somatization.

\section{Key words}

narratology, seeing, knowing, television, September $11^{\text {th }}$ 


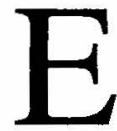

m 1985, quando eu pedi a Gérard Genette que lesse o manuscrito de meu segundo livro, ele achou que eu deveria alterar o título que tinha escolhido: Voir et savoir [Ver e saber]. Assim como é, disse, não é muito sexy. Cedi, então, e voltei ao assunto com uma nova proposta, L'Oeil-caméra [O Olho-câmera], que lhe parecia melhor. Embora admitindo pelo recuo que ele tinha razão do ponto de vista editorial, sempre guardei uma certa frustração de ter retirado essas três palavras que resumiam muito bem minha proposta. Imagine-se então quanto gostei do convite para este colóquio: terei, finalmente, a oportunidade de falar sob o estandarte desse título apressadamente abandonado e de estruturar meu propósito sobre esse tema. No entanto, refletindo sobre o assunto, admito que tudo o que reúno, hoje em dia, sob esses termos, não tem muito que ver com o que eles abrangiam na época em que eu me dedicava à Narratologia comparada. Primeiro, porque os conteúdos que esses termos admitem já não são os mesmos: prọvinda, originalmente, do campo literário, a Narratologia voltou-se, a seguir, para o Cinema e a Televisão. Assim, pela mudança do campo de aplicação, os conceitos sofreram uma mudança profunda. E é dessa mutação paradigmática que eu gostaria de falar aqui.

\section{Do saber do narrador ao saber do espectador}

De fato, até os anos 70 - por surpreendente que isso possa parecer - os conceitos ver e saber não se distinguem. Quando os teóricos da literatura falam do ponto de vista, eles usam os termos visão (Pouillon) ou o saber (Todorov) indiferentemente. ${ }^{1}$ Quanto a

1. (...) ce que l'on nomme couramment le point de vue, ou, avec Jean Pouillon et Tzvetan Todorov, la vision ou l'aspect (Genette, 1972, p. 206). 
Genette, ele passa de um ao outro, sem prestar muita atenção. Num primeiro momento, Figure III (1972) define o ponto de vista em termos cognitivos, por igualdades ou desigualdades. Assim, o autor escreve que o relato está em focalização interna (Narrador $=$ Personagem) quando o narrador diz somente o que sabe tal personagem ${ }^{2}$ e, algumas páginas mais para frente, que trata do critério da visão que permite definir o ponto de vista, Genette fala, por exemplo, da cena do fiacre de Madame Bovary, sendo narrada desde o ponto de vista de uma testemunha exterior ${ }^{3}$ ou de uma cena em que a testemunha não é personificada, mas permanece um observador impessoal $^{4}$ ou que a focalização interna implica a desaparição da personagem. ${ }^{5}$ Esse deslizamento do cognitivo ao perceptivo consuma-se quando Genette cita, como exemplo de focalização interna, um filme: Rashomon (1951), de Akira Kurosawa.

O fato de que o fundador da Narratologia literária não achou outro exemplo melhor do que um filme para caracterizar uma categoria vigente no âmbito da literatura, metodologicamente, pareceme difícil de aceitar, sobretudo, porque esse filme, que encena quatro versões de um crime, não respeita a exigência atribuída por Genette à focalização interna, de que a personagem focalizada não seja descrita nem designada desde um ponto de vista exterior. Embora o filme compartilhe da restrição cognitiva, Rashomon - o modelo desse tipo de focalização - mostra as personagens determinadoras do relato, o que contrasta com o critério alegado por Genette.

Em L'Oeil-caméra, chego à conclusão de que o ponto de vista perceptivo e o ponto de vista cognitivo não se harmonizam numa mídia como o cinema, que usa o ponto de vista como um traço constitutivo de linguagem, e limito essa distinção conceitual

2. Narrateur $=$ Personnage (le narrateur ne dit que ce que sait tel personnage) (ibidem, p. 206).

3. (...) la scène du fiacre dans Bovary, qui est entièrement racontée selon le point de vue d'un témoin extérieur (ibidem, p. 208).

4. (...) le témoin n'est pas personnifié, mais reste un observateur impersonnel (ibidem, p. 208).

5. (...) le principe même de ce mode narratif implique en toute rigueur que le personnage focal ne soit jamais décrit, ni même désigné de l'extérieur (ibidem, p. 209). 
no âmbito do romance, ao qual Genette (1983) recorre em sua narratologia revisitada. Ao caracterizar a focalização pela definição do ponto de vista cognitivo, acrescento os termos ocularização, para designar o ponto de vista visual, e auricularização, para o ponto de vista auditivo.

Contudo, no fundo do conceito da tripartição genettiana da focalização há um elemento que ainda me incomoda: a falta de homogeneidade dos traços definidores, sobretudo, com respeito à focalização-zero. Ora ela equivale ao relato não-focalizado ${ }^{6}$, como sugere, aliás, sua nomeação, ora é sinônima da onisciência do romancista clássico ${ }^{7}$. Mais uma vez, a passagem pelo cinema tem uma virtude heurística: qualquer espectador deixar-se-á convencer facilmente que o encadeamento de posições da câmera a seu bel-prazer sem tomar em consideração tal ou tal olhar de personagem - e a construção de uma montagem alternada, pela qual o espectador consegue a vantagem cognitiva sobre as personagens, não dão o mesmo resultado. O fato dè que, no final do North by Northwest (1959), Hitchcock decidiu entretecer uma série narrativa na qual Guy quer ganhar sua partida de tênis antes que Bruno chegue ao local do crime, para depositar ali o isqueiro do jogador, evidentemente, não tem nada que ver com um pretendido relato não-focalizado.

$\mathrm{Na}$ verdade, essa configuração narrativa era o sintoma de um funcionamento perturbado do paradigma narratológico: ao aplicar como critério a relação do saber, para unir o narrador à personagem - posicionando-se assim do lado da produção, de acordo com a expressão onisciência do romancista -, não se tomava em conta que essa construção do ponto de vista só explica os efeitos sobre o leitor ou o espectador. De certo modo, Genette admite isso, dez anos mais tarde, em Nouveau discours du récit (1983), ao definir

a onisciência, termo que, na ficção pura, é literalmente absurda (o autor não precisa saber nada, já que inventa tudo)

6. (...) récit non-focalisé (Genette, 1972, p. 206).

7. (...) la focalisastion-zéro, c'est-à-dire l'omniscience du romancier classique (ibidem, p. 222). 
e que seria melhor substitui-lo por informação completa - o que implica o leitor tornando-se onisciente. ${ }^{8}$

Preso à imanência textual, Genette ainda não pode ultrapassar o limiar libertador. E é isso o que eu fiz, ao substituir a expressão vaga focalização-zero pelos conceitos focalização espectatorial ou focalização lectorial que, na minha opinião, tomam mais em conta o que o relato provoca no espectador.

Voltamos a essa situação narrativa, constitutiva do cinema, que pretende levar em conta o que sabe a personagem (focalização interna), mostrando-a desde fora. Vou citar uma seqüência de um filme muito mais famoso do que Rashomon, aquela em que Kane e Leland chegam num fiacre perante o investigador. Escutamos suas conversas, enquanto Bernstein, o narrador desse flash-back, entra em cena um pouco mais tarde, sentado sobre uma pilha de móveis carregados numa carriola. Porque aceita o espectador essa inverosimilhança conceitual sem protestar? Sem dúvidã, porque compreende a montagem como uma tentativa de restituição de meio-ambiente cognitivo de Bernstein, que não se reduz ao que é mostrado, mas se pretende que seja mais amplo. Esse flash-back teria então a função de compartilhar com o espectador as hipóteses manifestas naquele contexto. Se essa pequena paralepse não é tomada ao pé da letra, é porque o espectador compreende que o filme quer comunicar uma impressão, e não a restrição do campo perceptivo.

Precisei abandonar o terreno da imanência textual e abrir caminho à Narratologia por uma aproximação narratológica que atenda, ao mesmo tempo, ao autor e ao receptor. Mas essa primeira

8. (...) la focalisastion-zéro, c'est-à-dire l'omniscience du romancier classique (ibidem, p. 222). l'omniscience, terme qui, em fiction pure, est littéralement absurde (l'auteur n'a rien à savoir puisqu'il invente tout) et qu'il vaudrait mieux remplacer par information complète - muni de quoi c'est le lecteur qui devient omniscient (ibidem, p. 43).

Notamos que Genette usa aqui o termo autor, enquanto, em Figures III, só fala de narrador. Hesita ainda, uma página antes da passagem citada, quando escreve: le narrateur ou, si l'on veut sortir des conventions de la fiction, l'auteur-luimême [o narrado ou, se preferimos sair das convenções da fiç̧ão, o próprio autor] (ibidem, p. 48). 
abertura mostrou-se insatisfatória quando, deixando o cinema provisoriamente de lado, eu me propus a construir uma moldura conceitual apta a pensar os programas e a programação televisiva. Em contraposição ao espectador de cinema que, geralmente, sabe ao que vai assistir por ter consultado um programa ou olhado as fotos expostas na entrada da sala de cinema, o telespectador, em numerosas circunstâncias, pode assistir a imagens sem ter a menor informação sobre elas.

\section{A experiência do telespectador}

$\mathrm{O}$ atentado de 11 de setembro corroborou-me essa convicção e vou citá-lo aqui como exemplo heurístico. Cada um de nós, um dia, comparou com seus amigos seu 11 de setembro, deslocando esse evento histórico para a própria pequena História. Entre todas essas que eu ouvi pessoalmente, há uma que chamou mais minha atenção do que outras: a história de um amigo que descobrira essas imagens ao passar de um programa para outro: primeiro, ele pensou num filme-catástrofe para um público adolescente; depois, quando notou que dois canais das emissoras públicas divulgavam o mesmo programa, ele pensou numa greve... $\mathrm{O}$ fato de ter assistido sem horror à destruição de dois edifícios, acreditando que se tratava de um programa de ficção, mostra até que ponto o saber sobre o status das imagens é determinador em sua recepção.

Por tratar-se de uma mídia que mostra imagens de diferentes gêneros e que gosta de misturá-los, é preciso construir um sistema que explique a concepção, a estruturação e também a recepção dos programas (na óptica pragmática que é minha). Nessa perspectiva, eu digo que cada gênero se ancora numa promessa de relação a um mundo, cujo modo ou cujo grau de existência condicione a adesão ou a participação do receptor. Em outras palavras, um documento no sentido mais amplo - seja escrito ou audiovisual - é um produto em função de um tipo de crença adotada pelo destinatário e, por outro lado, esse documento não pode ser interpretado pelo receptor sem ter alguma idéia prévia sobre o tipo de laço que o une com a realidade. 
A primeira questão é saber se esses signos se referem a objetos existentes dentro de nosso contexto real ou a puras quimeras ou entidades fictícias. Sem considerar as deformações que eles impõem à realidade, o filme documentário ou o telejornal pretendem referenciar-se ao nosso mundo, dando-nos informações, para ampliar nosso saber sobre ele. A todos esses gêneros, a televisão junta a emissão ao vivo, proporcionando-nos a impressão de ter acesso direto aos eventos, de ser testemunhas do mundo, como o notava Rudolf Arheim desde o ano 1935.

Há três razões para poder tomar a sério um documento audiovisual apresentando-se como referencial ao mundo:

- Como signo do mundo, pretendendo depor veridicamente sobre o mundo (atualidades, telejornal, reportagens);

- Como signo do autor, exprimindo uma verdade profunda de indivíduos que nos vêm à cabeça quando se fala de sentimentos autênticos, seja em depoimentos, emissões ao vivo ou informações redigidas por indivíduos cuja autoridade é ilesa (valorização de um documento em vista da personalidade de seu autor, por exemplo: o filme do escritor Hervé Guibert, atingido pela AIDS, dando informações sobre seu estado de saúde fatal);

- Como documento que contém uma verdade incontestável (o que é o papel do arquivo).

De acordo com uma alternativa interpretativa, o outro mundo, no qual o telespectador está prestes a situar as imagens, é o mundo fictício. Os objetos, as ações, todos os signos da ficção fazem então referência a um universo imaginário, mental, e exigimos que eles sejam dispostos de tal maneira que a coerência do universo criado, com todos seus postulados e propriedades em que ele se funda, seja respeitada. Pertencem ao mundo da ficção os filmes, os telefilmes, os folhetins, as séries e as comédias situacionais: a diferença entre essas emissões manifesta-se nas modalidades do grau da imitação da realidade.

O acontecimento do 11 de setembro permite observar que as imagens só se tornaram horríveis a partir do momento em que foram conectadas com o mundo real. De um ponto de vista semiológico, certamente, podemos admirar-nos de que os espectadores da cena - 
inclusive, por parte, os observadores profissionais - não tenham notado que faltava um índice para que essas imagens ao vivo se intrometessem no universo do Dia da Independência: o raccord do olhar. Voltarei mais tarde a esse assunto, mas, antes, vamos a fundo no mundo da televisão.

Umberto Eco, que foi um dos primeiros a mostrar o papel da oposição informação versus ficção dentro da categorização dos programas televisivos, observava que há um tipo de emissão difícil de definir nesse contexto: o jogo. Será que fala a verdade ou que encena uma ficção? (1983: 203). A resposta não é fácil. Umberto Eco chega à conclusão de que há uma mistura entre realidade e ficção. Ao seguir minha definição do gênero como promessa de uma relação com um dos mundos, é preciso ser mais exato. Até agora, tomamos em consideração duas maneiras de fazer mundos: seja, referirse a nosso meio ambiente - que convencionalmente chamamos de realidade -, ou seja, referir-se a um mundo mental. Em ambos os casos, os signos aspiram a uma certa transparência, sobretudo quando se trata de imagens e de sons: eles ocupam menos importância do que aparentam. Mas acontece que o signo remete a si mesmo, de um modo auto-reflexivo, e, ao mesmo tempo, remete a um objeto. Essa transparência-com-opacidade, conforme os linguiistas, define-se pelo fato que o signo, nem transparente nem opaco é, ao mesmo tempo, transparente e opaco, reflete-se ao mesmo tempo em que ele representa alguma coisa diferente de si mesmo (Récanati, 1979: 21).

Essa determinação do signo em si (um movimento da câmera muito cuidadoso ou um cenário artificial, por exemplo) remete a um dos traços que define o jogo, e ao falar de sua gratuidade é a isso, além de tudo, que alguns se referem. De fato, conforme o Larousse, o jogo é uma atividade física ou intelectual não imposta e gratuita, a qual alguém se dedica para divertir-se $e$ ter prazer [os grifos são meus.${ }^{9}$ Essa gratuidade tem graus ${ }^{10}$. Primeiro, os jogos que se agrupam sob a categoria que Caillois chamava de ilinx - palavra grega

9. Activité physique ou intellectuelle non imposée et gratuite, à laquelle on s'adonne pour se divertir, en tirer un plaisir.

10. Retomo aqui os conceitos de Caillois, considerando-os, porém, sob o ângulo da gradação, o que foge de seu propósito. 
que significa, ao pé da letra, remoinho de água; trata-se de jogos em redor da procura de vertigem, volteio, caídas, deslizamentos, etc., que são essencialmente lúdicos - ao contrário dos jogos de interpretar um papel, cuja moldura é o mundo real. Segundo, os jogos de imitação (mimicry) que partem da simulação e não criam seus próprios mundos ficcionais: o jogo da prenda, aquele que prescreve a um jogador de interpretar um papel, a paródia de um dispositivo televisado, a imitação de um cantor ou de um político, etc. Dá para perceber que os jogos estão longe de formar uma categoria homogênea. Alguns engajam a realidade (os jogos de interpretar um papel, os concursos ou quizzes, cujas soluções são verificáveis no mundo real, etc.); e outros se baseiam na ficção. Os mais gratuitos entre eles embasam o jogo pelo jogo (e outros, a arte pela arte).

Num contexto diferente, a tomada de um prédio desmoronando-se poderia suscitar um efeito puramente lúdico: por exemplo, montado depois de um plano em que um homem sai do estúdio, batendo a porta... (vi, aliás, essa montagem bem antes do desmoronamento do World Trade Center).

À verdade da informação, que adota o mundo como referência, e à falsidade da ficção, que mira o universo mental, precisamos ainda juntar a categoria do riso, na qual o objeto em si é a mediação, seja brincando com a língua (enunciação), jogando com o jogo (acaso) ou fazendo arte pela arte. Para categorizar essa terceira possibilidade lógica, proponho o termo de mundo lúdico. Será que o adjetivo reflexivo designaria melhor essa volta sobre si mesmo, caracterizando a enunciação como jogo pelo jogo? Falando em termos semióticos, acredito que sim. Mas lúdico aponta melhor o benefício simbólico prometido ao espectador ou sentido por ele.

Será preciso incluir nesse mundo lúdico o cinema e as emissões televisivas de segundo escalão, ou seja, aquela produção reflexiva que focaliza outros filmes ou outras emissões conhecidas ou as convenções de um gênero. A publicidade, em primeiro lugar, é muito apegada a todos esses jogos.

Resumindo: os três mundos - o real, o fictício e o lúdico podem ser esquematizados da seguinte maneira: 
LÚDICO

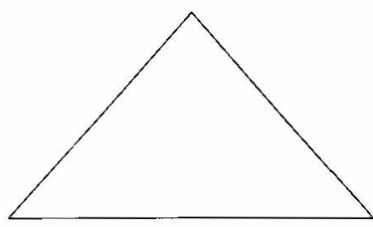

REAL

FICTÍCIO

Partindo desse esquema, podemos concluir que a identificação do mundo ao qual se remetem as imagens precede a compreensão e a recepção do visto. Quais são as consequiências dessa conclusão quando se trata da interpretação de um acontecimento que o espectador categoriza como real? Para responder a essa pergunta desde um ponto de vista semiótico, vou trabalhar com o que se chama a violência das imagens.

O topos do 11 de setembro é a violência das imagens, pretendendo que, na transmissão ao vivo do desmoronamento das duas torres, teríamos sido confrontados com imagens de uma violência extrema. Essa tese combina muito pouco com a reação de cada um. Entre os numerosos relatos dos telespectadores, há poucos (pessoalmente, não conheço nenhum, mas nunca se sabe), que testemunhe um espanto tão grande que ele teria desligado seu televisor. No entanto, é grande o número daqueles que confessaram sua perplexidade, como se a imagem de um avião chocando-se com um prédio os tivesse transformado em estátuas de sal.

Se a imagem tivesse sido tão violenta como dizem, como poderíamos ter ficado frente à tela? Não teríamos tentado pôr em prática toda uma estratégia de evitação, como uma criança, refugiando-se em seu quarto quando uma imagem a terrifica e dando, ao mesmo tempo, uma olhada fugitiva? ${ }^{11}$ Para responder a essas perguntas, não adianta opor nosso comportamento adulto insensível e

11. Penso na anedota que Tisseron conta sobre seu filho apavorado por um faroeste, correndo refugiar-se em seu quarto ao menor tiroteio. Cf. Le chavirement du cadre des images [ $O$ virar da moldura das imagens]. Dossiers de l'audiovisuel $\mathrm{n}^{\circ}$ 104: $\dot{A}$ chacun son 11 septembre [A cada um seu 11 de setembro], julho-agosto de 2002, p. 52. 
acostumado a todos horrores. Apostamos que aqueles que ficaram colados à televisão não suportam a visão do olho sendo cortado de Un chien andalou, e que seus avôs ou bisavôs se espantavam pela entrada de um trem na estação de La Ciotat. É preciso admitir que a queda das tuas torres não conseguiu suscitar o mesmo recuo quase reflexivo. Na França, TF1 e France 2, as duas emissoras mais poderosas, prescindiram de interromper a difusão de suas séries, para transmitir o acontecimento: ambas esperaram até o final da projeção do filme respectivo. ${ }^{12}$

Chocou a atitude estética de Stockhausen que viu nessas imagens a última obra de arte do século XX. No entanto, se por um lado o telespectador $\mathrm{X}$ pôde assistir a essa emissão ao vivo sem pestanejar e, por outro lado, o músico viu nela uma obra de arte, não seria isso um indício de que - em vez de acentuar a priori a violência dessas imagens - precisamos encarar a hipótese da ausência de violência e investigar, primeiro, sobre o que significa esse sintagma da imagem violenta? Reformulemos a pergunta frontalmente: porque as primeiras imagens do atentado de 11 de setembro não são imagens violentas? Porque elas foram - sim - assombrosas, porém suportáveis?

A primeira resposta tocaria o lado do saber e das enciclopédias: essas imagens lembravam imagens já vistas, às quais estávamos acostumados, como a demolição de um quarteirão de prédios de uma cidade-satélite. ${ }^{13}$ Embora isso seja verdade, a resposta fica insatisfatória. Uma outra explicação foi fornecida bem mais tarde, ao contrário, quando vimos o plano de uma mulher, escondendo-se atrás de um carro, para proteger-se contra a imensa nuvem de pó e escombros que estava invadindo a rua. Esclarecia-se então que, se o plano geral de Manhattam, com seus dois aviões cortando o céu azul, tinha sido possível - inclusive lindo - de assistir para muitos dos telespectadores que não o confessaram tão francamente como

12. TF1 mostrava o telefilme Le Mari d'une autre [O Marido de uma outra] e France 2 o episódio La Chanson de l'ami [A Canção do amigo] da série Commissaire Lea Sommer [Comisário Lea Sommer]. Ambos eram programas reprisados.

13. P. Chauraudeau, La vérité prise au piège de l'émotion [A verdade pega na armadilha da emoção], Dossier de l'autovisuel nº 104. 
Stockhausen, foi porque aquela cena não estava na medida do homem, por falta de ancoragem num olhar humano e pelo ponto de vista sobre-humano, quase divino, da exibição dessa ação - cometida, além de tudo, em nome de Deus. E quem estudou o cinema dos primeiros tempos sabe que a mera exibição (Gaudreault usa 0 termo monstration) não poderia suscitar muita emoção. Para que esse nobody's shot - na linguagem dos técnicos americanos - fosse animado,$^{14}$ precisava-se de um raccord de olhar que ativasse $o$ que eu já tinha chamado, alguma vez, um antropomorfismo regulador. ${ }^{15}$ Não sei se nós assistimos a uma cena primitiva, como diz Baudrillard (de fato, sei que não), em todo o caso, uma coisa é certa: revivemos em alguns minutos a efetivação do dispositivo cinematográfico num plano geral e sob a ausência do olhar humano, o que impede a compreensão do que está sendo mostrado pela falta de um pregoeiro mais informado do que o são os próprios espectadores.

Frente a um plano geral fixo, como seria possível ir além da descrição? Na hora da retransmissão, em pseudo ao vivo, da revolução romena, já tínhamos feito a experiência da não-eloquiência das imagens ou da incapacidade da imagem de narrar pela ausência do saber lateral sobre a realidade. Revivemo-lo no dia do 11 de setembro. O que significa o visível? - foi a interrogação de todos os comentaristas das redes públicas ou privadas no momento da primeira colisão. E era difícil ir além da uma simples observação: um avião percute o WTC. Zunzunegui faz um diagnóstico do mesmo gênero, ao afirmar que

essas imagens somente adquiriram uma dimensão informativa a partir do momento em que se produziram dois eventos ligados, mas não concatenados: o primeiro está ligado ao desenvolvimento dos fatos (indo junto com um nascimento

14. L. Jullier, Images sans témoins. La place du spectateur dans le journal télévisé [Imagens sem testemunhas. O lugar do espectador no telejornal]. La communication de l'information. Paris, L'Harmattan, 1996.

15. F. Jost, Un monde à notrè image. Énoncition, cinéma, télévision [Um mundo a nossa imagem. Enuciação, cinema, televisão]. Paris, Méridiens Klincksieck, 1992. 
progressivo do sentido: um avião explode: acidente; dois aviões explodem: terrorismo) e pelo seu caráter de sintagma temporal que modifica o sentido do discurso que ele produz na medida que se põem no lugar os elementos do quebra-cabeça. ${ }^{16}$

Ao estender-me sobre a mudança narrativa provocada pelo segundo choque, eu não a consolidaria no discurso audiovisual. $\mathrm{O}$ terreno de experimentação da recepção que constituiu o comentário dos jornalistas ao vivo, afirma, de fato, que o primeiro repertório de estruturas cognitivas mobilizadas para compreender o evento não se referia aos aviões, senão... a uma camionete! Cabe lembrar que David Pujadas, o apresentador de France 2, não procurou explicações na estrutura narrativa subjacente à imagem (de tipo: dois aviôes explodem: terrorismo), senão no contexto do evento, que lhe lembrava primeiro (às $15 \mathrm{~h} 37 \mathrm{~min}$.) o atentado de 1993, originado pela explosão de um veículo no estacionamento das torres. Referente às testemunhas imediatamente interrogadas, não houve consciência de ter visto aviões de linha. Alguns evocaram um avião particular (France 2 , às 15h43min.), outros um Falcon (TF1, às 15h43min.). Admito que, da minha casa, eu tive a mesma sensação. Essas reações, profissionais ou não, demonstram a dificuldade que os espectadores, diretos ou indiretos, tiveram para construir um esquema capaz de sintetizar a diversidade perceptível, o que Schank chama, no caso, Memory Organization Packet (MOP) ${ }^{17}$ A memória não era suficiente para interpretar o mundo; precisava-se de imaginação, como o atesta o comentário de um dos jornalistas de France 2, Daniel Bilalian, alguns minutos depois (às 15.53 horas): $E$ difícil imaginar que essas imagens são bem reais, que elas não proviessem de um filme de ficção científica. ${ }^{18}$

16. S. Zunzunegui, Le futur antérieur [O futuro anterior], Dossier de l'audiovisuel $\mathrm{n}^{\circ}$ 104, p. 17.

17. Schank define o MOP da seguinte maneira: A memory structure that groups together actions with a share goal that occurred at the same time. Dynamic Memory, Cambridge University Press, 1982, p. 95.

18. (...) la focalisastion-zéro, c'est-à-dire l'omniscience du romancier classique (ibidem, p. 222). On a du mal à imaginer que ces images sont bien réelles, qu'elles ne sont pas sorties d'un film de science-fiction. 
Essa ruptura do funcionamento cognitivo (da memória à imaginação) era um tanto mais brutal pelo fato de que o nobody's shot nos deixava, para dizer assim, do lado de fora. Para traçar o caminho que conduzisse da experiência do mundo à sua construção cognitiva, precisava-se da capacidade de fazê-lo, aquém do visível, contra a corrente, e de considerá-lo como a última película de um cálculo de intenções, característico de um novo terrorismo: o terrorismo hermenêutico. ${ }^{19}$

A lição semiótica desse encaminhamento espectatorial é a dissociação profunda entre o ver e o saber. Mesmo parando a imagem (como alguns fizeram então), penetrando-a na maneira do fotógrafo de Blow up, confiado nos poderes da ampliação, ou analisando-a com câmera lenta, não mudava nada na compreensão do fenômeno. As explicações só podiam vir de outro lugar: já não de um como, senão de um porque. Ao mesmo tempo, essa retransmissão arruinou definitivamente a idéia de uma análise imanente da imagem e assentou a necessidade de uma teoria de inspiração pragmática: já que a linguagem imagética não nos dava mais informação do que o próprio espetáculo do mundo, surgia a questão sobre as intenções de aqueles que tinham transformado o mundo em imagens. Essa foi, sem dúvida, a tomada de consciência mais dura: as imagens não se referiam a nenhum fenômeno conhecido da memória humana, mas elas tinhas sido vistas antes por outros, pelo menos na imaginação. O visível tinha sido encenado por uma instância invisível.

A essa perda de confiança na transparência da imagem, será preciso juntar um choque frente à violência das imagens?

Para responder a essa questão, o prévio excurso teórico convence-me a tratar de um modo diferente as imagens que deixam ver a violência daquelas que sabemos que elas têm efeitos violentos na realidade, mesmo não sendo todos visíveis. Partindo deste ponto de vista, as primeiras imagens do 11 de setembro pertencem à segunda categoria: tal como o horror do massacre de Timisoara era na dimensão dos 12 mil mortos anunciados (embora não mostrados) por Bilalian, o apresentador do telejornal do segundo canal francês,

19. D. Dayan, Cui bono?. Dossiers de l'audiovisuel $\mathrm{n}^{9} 104$, p. 28. 
aquele do 11 de setembro correspondeu a 40 mil mortos estimados, nas primeiras horas, pelos jornalistas, cuja avaliação dependia de um simples cálculo de probabilidade.

Nesse sentido, não partilho a opinião daqueles que introduzem seu raciocínio psicanalítico sobre o 11 de setembro pelo horror que [as imagens] mostravam. ${ }^{20}$ Longe de negar o horror suscitado pelo acontecimento, mas, precisamente, porque ele não se produziu no nível da qualidade sensível, como diria Peirce, ao falar do icônico. O horror resultou do pensamento do telespectador sobre o acontecimento e do que ele podia imaginar além do visível. Às $15 \mathrm{~h} 33 \mathrm{~min}$., em France 2, David Pujadas intervém ao vivo para anunciar explosões muito espetaculares e informa que se fala de vários mortos, no mínimo, e de dezenas de feridos. Esse balanço, em si muito comedido, muda pelo tom do comentário quando outro jornalista do canal toma a palavra, para descrever a imagem ao vivo: Interrompo, acho que em Nova York uma das torres desmoronou... A partir desse momento (às $15 \mathrm{~h} 59 \mathrm{~min}$.), a imaginação libera-se, saindo do terreno da hermenêutica, para adotar o ponto de vista das vítimas. No momento do desabamento da primeira torre, às $16 \mathrm{~h} 00$, Pujadas exclama é difícil imaginar o que está acontecendo no interior. Podemos imaginar que no solo, houve outros danos. Seis minutos depois, a agitação imaginativa funciona a toda marcha: A gente não ousa imaginar $o$ balanço dessa catástrofe inimaginável (Pujadas)... É preciso imaginar que se trata da Bolsa. Imaginemos a Bolsa com dois aviões [...]. Podemos imaginar que os feridos são contados por dezenas (Bilalian)....

\section{Violência deduzida, violência percebida}

A maioria dos escritos sobre a violência da imagem não distingue entre a violência representada na imagem e a violência construída pela imagem. Para remediar esse estado das coisas, proponho tomar em consideração a distinção já anunciada entre signos do mundo e signos do autor (Realta/Finzione, 2003), que são duas

20. S. Tisseron, op.cit, p. 51. 
maneiras de encarar as relações pragmáticas do signo (ou representamen, segundo Peirce) com seu objeto:

- Como ícone, a imagem remete ao motivo ou ao mundo, como o postulam as problemáticas da representação ou da analogia. Quando se fala de imagem violenta, em geral, é por abuso lingüístico, para designar imagens que mostram a violência do mundo.

- Como índice, a imagem ancora no que é a sua fonte ou em quem a utiliza. Assim, a imagem é signo do autor, se admitimos sob esse termo não só uma entidade cheia e romântica, senão a instância antropomórfica - ou não - que a origina. Partindo desse ponto de vista, o fosso é grande entre as imagens automáticas feitas da torre de CNN, captando o atentado do WTC, e as imagens somáticas, como aquelas que vimos depois e que guardam os movimentos do corpo e as emoções do homem da câmera.

\begin{tabular}{|c|c|c|}
\hline $\begin{array}{l}\text { Signos do mundo } \\
\text { (ícone) } \\
\text { (indice) }\end{array}$ & Violência dentro da imagem & $\begin{array}{c}\text { Sem violência dentro } \\
\text { da imagem }\end{array}$ \\
\hline $\begin{array}{l}\text { Imagens violentas } \\
\text { (índices somáticos) }\end{array}$ & $\begin{array}{l}\text { Olhar sobre o atentado do } \\
\text { WTC (à altura do homem) } \\
\\
\text { Percurso de Naudet dentro do } \\
\text { WTC, junto com os bombeiros } \\
\text { (Nova York: } 11 \text { de setembro) }\end{array}$ & $\begin{array}{l}\text { Pó ocultando a tela de Naudet } \\
\text { (Nova York: } 11 \text { de setembro) }\end{array}$ \\
\hline $\begin{array}{l}\text { Planos do WTC realizados } \\
\text { do helicóptero }\end{array}$ & $\begin{array}{l}\text { O atentado do WTC filmado } \\
\text { do prédio de CNN } \\
\text { Nobody's shot }\end{array}$ & $\begin{array}{l}\text { Realidade filmada em } \\
\text { ocularização zero }\end{array}$ \\
\hline
\end{tabular}

\section{Violência da imagem e violência do mundo}

Enquanto as imagens predominantemente icônicas ${ }^{21}$ constroem uma vista não marcada do mundo, favorecendo a transparência, na medida em que elas não revelam nenhuma presença humana

21. Parto da idéia de que toda imagem cinematográfica ou vídeográfica é um ícone indicial, como disse J.-M. Schaeffer sobre a foto (L'Image précaire [A Imagem precária], Le Seuil, 1987). Ao falar, no seguinte, de imagens predominantemente icônicas ou indiciais, sei muito bem que, desde o ponto de vista de Peirce, não é ortodoxo diferenciar entre as imagens interpretadas como ícones e aquelas interpretadas como índices. 
atrás da câmera, as imagens predominantemente indiciais atestam um olhar e, assim, uma identifícação antropomórfica, uma visão à altura de homem, deixando imediatamente apreensível a violência, da qual o outro é vítima. Como eu disse, essa violência expressou-se pela primeira vez nas imagens de uma mulher, refugiando-se atrás do porta-malas de um carro: imagens feitas por um homem também preocupado em fugir do perigo. Mas esse perigo foi sentido verdadeiramente, quer dizer, corporalmente, só um ano depois, ao poder assistir ao que tinha visto um dos irmãos Naudet acompanhando os bombeiros dentro do WTC. ${ }^{22}$ Em primeiro lugar, paradoxalmente, porque o som nos aproximou da imagem. O plano geral compartilhava seu mutismo com as experiências do começo do cinema, incluído na hora do desmoronamento do WTC. Através das imagens do mergulhador submerso na realidade, segundo uma expressão de Edgar Morin, a gritaria, as vozes e as sirenas deixavam perceber a confusão, facilitando a identificação do visto com o vivido. Segundo elemento violento: o recuo do realizador do filme frente a certas cenas que ele recusou filmar (duas pessoas queimando-se), os movimentos testemunhando uma hesitação sobre o que deveria ser olhado e, sobretudo, o próprio enfocado do olho da câmera. Terceiro graū de violência indicial: a imagem girando, tornando-se abstrata e mostrando manchas de cor num turbilhão brutal, que corresponde ao momento em que o realizador do documentário foi jogado ao solo pelos bombeiros que o acompanhavam.

O que então se vê, em si, não é violento: uma tela escura ocultando a realidade, dedos em primeiríssimo plano e, finalmente, a paisagem da rua em que os contornos reaparecem progressivamente quando a poeirada se desfaz... Tal plano poderia também fazer parte de um filme experimental ou de um filme de Marguerite Duras, como Son nom de Venise dans Calcutta désert. Não contém em si nenhuma violência. $E$ apesar de tudo, seu efeito é mais forte do que qualquer outro, porque vivemos o apocalipse junto com aquele homem que o vive. Já não se trata de saber ou de ver, senão de sentir a violência.

22. New York: 11 septembre (Realização: Jules e Gédéon Naudet), transmitido no dia 11 de setembro de 2002, em Des Racines et des ailes, em France 3, às 20h56min. 
O 11 de setembro deixou-nos experimentar vários tipos de violência, o que nosso gráfico tenta categorizar. $O$ plano geral do WTC, filmado desde o prédio da CNN, testemunha, sem dúvida, uma violência do mundo por um olhar exterior, um nobody's shot. Muito rápido, juntaram-se a essa vista imagens filmadas dos helicópteros, que mostraram as torres sob diferentes ângulos e que deixaram entrever, mais ou menos, a visão investigadora de uma instância antropomórfica, na procura de fendas causadas pelos aviões. No entanto, a violência só foi tangível quando a enunciação se ancorou verdadeiramente na visão da mulher apavorada e, bem mais tarde, na visão das vítimas (filmagem de Naudet). Essa identificação com o corpo do cineasta, essa construção de uma humanidade por trás da câmera, tem efeitos tão fortes que ela pode infundir violência num objeto que, em si, não é violento, como no caso da ocultação brutal da câmera pela poeira na rua em que se encontrava o realizador do documentário. Até é possível, em outros contextos, simular a violência ou - o que é o mesmo - submeter a violência num mundo sem violência. Os partidários do Dogma 95 , os jornalistas das revistas ou os cineastas dos jogos de aventura sabem muito bem: desde que vemos através dos olhos de um homem que corre, sentindo incidentalmente os abalos devido ao percurso, a mínima caminhada saudável adota a marca de um espetáculo agonizante, sobretudo, quando a respiração de um homem ou a palpitação cardíaca ritma o visual.

Resumindo: a imagem violenta caracteriza-se pelo fato que ela produz um choque perceptivo; a imagem $d a$ violência produz um choque emotivo, que não é forçosamente perceptivo. Se uma imagem de corpos esfomeados toca de imediato, independentemente dos parâmetros visuais mobilizados, mas por provocar uma identificação antropomórfica imediata (nenhuma é mais forte do que a identificação que passa por rostos olhando-nos), uma imagem de uma torre que se desmorona em poucos segundos só nos toca indiretamente, ainda mais porque sabemos que ela não mostra os sofrimentos ocultados (dito para o destroço do avião). A diferença não é mínima, e ela é ainda maior a partir do momento em que ligamos o que vemos ao mundo da ficção. A particularidade da ficção é 
mesmo poder inverter esse sistema de significações: o fato de ver imagens de violência (mortes brutais) é absolutamente suportável quando estamos cientes de que elas não prestam conta da violência do mundo, senão de uma realidade intencionalmente construída pela e para a câmera.

De Figures III às imagens do 11 de setembro, passando por Citizen Kane [Cidadão Kane]: o percurso pode surpreender. E não obstante, como terão compreendido, cada exploração da dupla verl saber não é um renegamento da precedente, senão uma evolução. Se, para mim, a passagem do texto do romance à imagem da mídia televisiva impõe uma mudança radical de paradigma, se o saber do espectador não poderia ser pensado como o saber do telespectador, só restam as categorias ajustadas dentro do âmbito de uma semiologia da imanência, que ainda é um instrumento útil, contanto que consigamos destinar-lhe o lugar propício dentro de uma paisagem mais ampla, por um vasto zoom para trás.

\section{Bibliografia}

CHAURAUDEAU, P. 2002. La vérité prise au piège de l'émotion, Dossier de l'autovisuel $\mathrm{n}^{\circ} 104$.

DAYAN, D. 2002. Cui bono?. Dossiers de l'audiovisuel $\mathrm{n}^{\circ} 104$, p. 28.

GENETTE, G. 1972. Figure III. Paris, Seuil. 1983. Nouveau discours du récit. Paris, Seuil.

JOST, F. 1992. Un monde à notre image. Énoncition, cinéma, télévision. Paris, Méridiens Klincksieck.

JULLIER, L. 1996. Images sans témoins. La place du spectateur dans le journal télévisé. La communication de l'information. Paris: L'Harmattan.

NAUDET, J. e NAUDET, G. 2002. New York: 11 septembre, em Des Racines et des ailes, em France 3, às $20 \mathrm{~h} 56 \mathrm{~min}$.

REALTA/FINZIONE. 2003. L'Impero del falso. Milano: Castoro.

SCHAEFFER, J.-M. 1987. L'Image précaire. Le Seuil, 1987 
SCHANK. 1982. Dynamic Memory. Cambridge: Cambridge University Press, p. 95.

TISSERON. 2002. Le chavirement du cadre des images. Dossiers de l'audiovisuel $\mathrm{n}^{\circ}$ 104: À chacun son 11 septembre, julho-agosto , p. 52.

ZUNZUNEGUI, S. 2002. Le futur antérieur. Dossier de l'audiovisuel $n^{\circ} 104$, p. 17. 